\title{
Article
}

\section{Enhancing Information Language Learning with Mobile Technology - Does it Work?}

Reinders, Hayo and Min, Young Cho

Available at http://clok.uclan.ac.uk/3317/

Reinders, Hayo and Min, Young Cho (2012) Enhancing Information Language Learning with Mobile Technology - Does it Work? Journal of Second Language Teaching and Research, 1 (1). pp. 3-29. ISSN 2045-4031

It is advisable to refer to the publisher's version if you intend to cite from the work.

For more information about UCLan's research in this area go to http://www.uclan.ac.uk/researchgroups/ and search for < name of research Group>.

For information about Research generally at UCLan please go to http://www.uclan.ac.uk/research/

All outputs in CLoK are protected by Intellectual Property Rights law, including Copyright law. Copyright, IPR and Moral Rights for the works on this site are retained by the individual authors and/or other copyright owners. Terms and conditions for use of this material are defined in the policies page.

\section{CLoK}

Central Lancashire online Knowledge www.clok.uclan.ac.uk

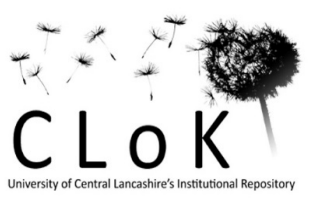




\title{
ENHANCING INFORMAL LANGUAGE LEARNING WITH MOBILE TECHNOLOGY - DOES IT WORK?
}

Hayo Reinders, Middlesex University, UK

Min Young Cho, University of Hawai'i, USA

\begin{abstract}
There are many theories that attempt to explain second language acquisition processes and factors determining success or failure. Despite a lack of general agreement between proponents of these theories, research has convincingly shown that the amount of exposure to target language input is one important predictor of ultimate achievement levels. 'Time on task' is as important in language learning as it is in many other domains (cf. Reber, 1993) and it is therefore important to identify ways in which this can be increased. An obvious possibility is to encourage learners to engage with (and in) the language outside the classroom. Informal learning, in the sense of learning outside of formal education, has been shown to be a major aspect of adult learning (Cross, 2007) and, given appropriate preparation and support, learners can greatly increase opportunities for learning if they can do so independently. Mobile technologies have obvious potential in this regard. However, is it possible to improve language skills in this way? In this article we report on an exploratory study into the use of cellphones for extensive listening practice. We used input enhancement to draw learners' attention to not only the meaning of the materials but also the formal (grammatical) aspects of the input. We found that the use of mobile technology presented a number of challenges and in this study did not result in learners acquiring the target structures. We conclude with a number of recommendations for the use and future study of mobile technologies for (language) learning.
\end{abstract}

Keywords: Mobile learning, SLA, input enhancement, enriched input, extensive listening, methodology 


\section{Introduction}

Technological innovation has influenced all areas of education, and the field of Second Language Acquisition (SLA) is no exception. Language teachers and SLA researchers have, since the 1960s, attempted to investigate and incorporate technology in language education, leading to the emergence of specialist fields such as computer-assisted-language-learning (CALL) and (more recently) mobile-assisted-language-learning (MALL). With the maturation of these academic fields, the emphasis has shifted to investigating the learning process and the ways in which technology can enhance or support this, rather than on the technologies themselves in line with the development in other subject domains (White, 2006).

Within the field of SLA exists a multitude of theories to explain language learning and inform language teaching practice, but there is no consensus or dominant theory (see R. Ellis 2008 for an overview). This is not to say there are no 'clusters of common understanding', or areas of broad agreement. R. Ellis, in a recent overview chapter (R. Ellis, 2008), identified ten such clusters. The one that we are most concerned with here is the empirically determined importance of ample access to second language input; there is quite literally no learning possible without target language input. Related to this, N. Ellis (2002) has shown convincingly that frequency effects play a major role in second language acquisition. Although input alone is not a sufficient condition for learning to take place, it is a necessary one, and the amount of input and the frequency of linguistic items therein have a direct relation with acquisition. A practical implication of this is the need to find ways for learners to be exposed to the target language.

The reality of language education around the world, however, is that most learners do not receive much exposure to the target language. Kaplan and Baldauf (1997) for example, estimate that, because of the small number of class hours that most learners receive and the large average class sizes in many countries, most learners only speak the language for a matter of minutes per week. Clearly, this has an impact on attainment levels. A practical challenge for language educators then is to find ways to encourage learners to engage with the language outside the classroom. Especially in foreign language learning situations where the target language is not spoken, one of the main difficulties reported by teachers is in helping learners find opportunities to use the target language and to adequately prepare them for interacting in it independently.

A related challenge is the limited time available during class to expose learners to extended texts; much of second language acquisition is based on the gradual uncovering of meaning 
in longer pieces of writing, or the ability to follow extended speech. By their nature these activities are time-consuming and can therefore only really be practised by learners themselves. Teachers find it difficult to encourage learners to engage in this type of practice.

One potential way of dealing with these challenges is through the use of mobile technology. Portable devices can offer opportunities for exposure to input outside the time and place constraints of the classroom and encourage 'integrative learning' (Warschauer \& Healey, 1998) whereby learning becomes continuous, and is not seen by learners as restricted to the classroom. In particular, for extensive listening practice, mobile technologies allow learners to engage with listening materials anywhere and at times convenient to them. In this article we describe the use of audiobooks loaded onto students' cellphones to encourage out-ofclass learning. In addition, we altered the audiofiles using a technique called 'input enhancement' (see below) to encourage attention to linguistic form as well as to the meaning of the stories.

Although a considerable body of research exists on the use of technology in language education, few studies have used mobile devices for the investigation of second language acquisition processes. We therefore now first review the literature on mobile-assisted language learning (MALL) and then review input enhancement as a language instructional technique, before presenting our own study.

\section{Literature Review}

\section{Mobile Learning}

The potential of mobile technology in the language classroom has gained increased interest in recent years (Chinnery, 2006). A range of devices such as mobile phones (e.g., Motiwalla, 2007; Thornton \& Houser, 2003), MP3 players (e.g., McCarty, 2005), and PDAs (e.g., Patten, Sanchez., \& Tangney, 2006) have been investigated for their use in language learning. Trifanova, Knapp, Ronchetti, and Gamper (2004, p.) defined mobile devices as '....any device that is small, autonomous and unobtrusive enough to accompany us in every moment", and Stockwell (2007) claimed that the term 'mobile' may refer to broader range of devices including wireless laptop computers, portable DVD players, and even handheld electronic games. As such, what endows technological products with mobile devices is their portability, or handheld size, which promises expansion of language learning contexts from solely classroom or computer laboratories towards informal, or out-of-class settings.

With the potential of ubiquitous, relatively cheap, and portable mobile devices, a variety of 
applications of mobile technology have been explored. One of the traditional applications includes its use for the delivery of content for language learning. For example, researchers adopted text messages as a means of providing vocabulary practice for quizzes and surveys (Levy \& Kennedy, 2005; Norbrook \& Scott, 2003), and for mini-lessons (Thornton \& Houser, $2001,2005)$. One survey into the use of mobile phones revealed that Japanese learners preferred their mobile phones over desktop PCs or PDAs for exchanging emails. Mobilebased email has also been used to encourage vocabulary learning and web-based video clips have been used to learn idioms through mobile phones (Thornton \& Houser, 2005). Moreover, Taiwanese learners found the mobile learning manageable as they could enjoy 'bite-size-chunks' of learning contents through the relatively small screen (Chen, Hsieh \& Kinshuk, 2008). This is a clearly pedagogic benefit that may, over time, inform the development of traditional teaching materials as well. In addition to content delivery, other studies utilized mobile devices for the purpose of promoting learner-learner interaction. For instance, Dias (2002a, 2002b) offered a web-board accessible via mobile phone so that learners could exchange text-based asynchronous exchanges.

A theoretically significant feature of mobile devices lies in their potential for situated learning (Kukulska-Hulme \& Traxler, 2005; Lave \& Wenger, 1991). As learning occurs outside of classroom, this also encourages context-driven learning. Ogata and Yano (2003) for example, built a 'location-aware' mobile learning system that takes account of the relative position of speakers (important in Japanese culture) and location (formal or informal) to recommend specific greetings and language to L2 learners of Japanese. Moreover, mobile devices minimise the separation between in-class and out-of-class learning (Reinders \& Lewis, 2009). Surprisingly, considering its obvious potential, mobile learning has received little attention in SLA research.

\section{Extensive Listening}

The purpose of extensive listening practice, usually considered as a counterpart of extensive reading, is to expose language learners to extended auditory input. Often this involves exposure to authentic materials such as news broadcasts, lectures, or fiction. In many cases the input may be simplified or altered in some way (for example, through the use of word lists or glosses) to enable learners of lower proficiency levels to understand the meaning of the texts. The focus in extensive listening (as in extensive reading) is on encouraging learners to move away from segmenting input into discrete items, such as processing words one by one or in small groups, to listening for meaning units. 
Lower level learners in particular often disengage from processing for meaning when they encounter one or more words they do not know; teachers use a variety of techniques to encourage them to break away from this habit such as 'skimming' and 'scanning' in reading, but although explicit (so-called 'strategy') instruction can be helpful, extensive listening can only really be learned through regular practice.

Although few studies have directly investigated the effects of extensive listening, it is generally believed that comprehensible and interesting listening materials will have benefits similar to those afforded by extensive reading materials. Studies on extensive reading have shown benefits for vocabulary acquisition, comprehension and even fluency, as well as having a positive impact on affective aspects of language learning, such as an increase in confidence (e.g., Adams, 1998; Day \& Bamford 1998). Similarly, extensive listening has been shown to be beneficial for pronunciation and speaking skills (Renandya \& Farrell, 2010) and recall. For example, Zhang (2005) compared two groups of middle school learners who received listening practice. One group had extended texts read to them by their teacher, in the form of interesting and comprehensible stories. The other group received systematic and intensive listening instruction. The extensive listening group outperformed the intensive listening group on cloze and recall tests (as cited in Renandya \& Fang, 2003). There are also potential affective benefits to listening to extensive, comprehensible texts (Renandya \& Fang, 2003) and many students report great satisfaction when they are first able to understand a news broadcast or a TV programme, for example (Ryan, 1998). Despite the potential importance of extensive listening for language development, few other studies exist. This was one of the reasons that prompted us to conduct our study.

\section{Input Enhancement}

Input enhancement describes a range of techniques for manipulating target language input in order to increase the saliency of certain linguistic elements in otherwise meaning-oriented activities. An example is the underlining or bolding of, for example, all past tenses in a written text, or the frequent use of the passive voice. The main focus is on reading and understanding the text (i.e. the primary focus is on meaning), but learners' attention is likely to be drawn to one or more formal grammatical aspects of the language at the same time. The theoretical rationale is the assumption that noticing facilitates acquisition, and that a grammatical item that is noticed in context and not in isolation, as for example in a grammar lesson, is more likely to be retained (Sharwood Smith, 1993) 
A range of input enhancement techniques exist. Visual input enhancement, including textual input enhancement as well as the use of visual aids, involves the inclusion of visual information (e.g. pictures) to highlight certain aspects of the text (e.g., Doughty, 1991). Other techniques include metalinguistic explanations (e.g., Fotos, 1994), increasing the frequency of the target form (e.g., White, 1998), explicit or implicit error correction (e.g., Spada \& Lightbown, 1993), or oral or written simplification of the text (e.g., Leow, 1993). These techniques differ with respect to how implicit or explicit they are; for example, metalinguistic explanation is relatively more explicit than the use of increased frequency of input or implicit error correction.

Studies into the effectiveness of visual input enhancement on grammar acquisition show inconclusive results. For example, a meta-analysis on visual input enhancement (Lee \& Huang, 2008) revealed methodological divergence among studies, for example, in terms of the target forms they investigated and the frequency of these forms in the texts. Other differences included the learners' levels and previous exposure to the target form. Nevertheless, quantitative analysis of the research revealed only a minimal advantage between participants who had been given enhanced texts, as compared to those who had been given unenhanced texts with no difference in terms of comprehension. Although at this point it is not possible to say that visual input enhancement is effective, more research needs to be done to investigate contextual factors such as prior knowledge of the target form, as well as the relative salience of the target form.

In the same way that texts can be visually enhanced, they can also be aurally enhanced, for example by increasing the volume of target items in the text, or by including a short pause before or after (or both) the target items. Although Gascoigne (2006) mentioned that an 'oral [our emphasis] equivalent of textual enhancement' could be achieved via stress, intonation, or gestures (p. 149), we are unaware of previous studies investigating this type of input enhancement and we thus believe our study is one of the first of its kind. 


\section{The Study}

\section{Research Questions}

This study investigated the following research questions:

1. What are the effects of aural input enhancement in extensive mobile listening practice on the acquisition of English 1) adverb placement and 2) passives?

2. How can mobile devices be used for 1 ) encouraging and 2) investigating extensive listening practice?

\section{Design}

To investigate the effect of the listening materials on language acquisition, we first established participants' prior knowledge of the target structures (see below). All participants completed a timed grammaticality judgement test (GJT) as a pre-test (see below) and were then randomly assigned to one of two treatment conditions: a control group, or an aural input enhancement group. Participants then listened to an assigned audiobook in their own time (in its original format for the control group, and enhanced for the aural input enhancement group) during a period of one week. At the end of the week they were given the same timed grammaticality judgement test (GJT) as a posttest.

Participants completed a debriefing questionnaire with questions about both the content of the book in order to measure their comprehension of the text, and were also asked about their experience of extensive listening practice, their use of the mobile devices, and the location and methods they had used to listen to the materials (See Appendix 1 ).

\section{Participants}

16 Korean learners of English participated in the study. All of them were freshmen enrolled in a university in Seoul, majoring in business. As part of their studies they took a course on 'Academic English for Business Majors', taught by one native English instructor. Their level ranged from 90 to 116 (out of 120) in IBT TOEFL, and 96 to 100 (out of 100) in national university entrance exam scores. We specifically targeted participants above intermediate level because we wanted to be able to give participants listening materials to complete outside the classroom. Participants therefore had to be at a level that would enable them to complete listening activities independently. 
A further 28 students agreed to participate but did not finish their listening within the time given. Their GJT results are not reported on below. However, we did include and report below on their responses on the questionnaire, which yielded interesting insights into the challenges of investigating naturalistic language learning.

\section{Target Structure}

The two English target structures were adverb placement and passive structures. English adverbs cannot be placed between their modifying verb and objective (e.g., *Mary kissed passionately John). This is not the case in all languages and has proven to be difficult for learners to fully master. As for the passive, although these forms are usually taught at a relatively low level, they are still difficult to learn because they do not follow the "first noun principle" (VanPatten, 1996), where learners usually perceive the first noun as an agent of an action. In this audio book, there were approximately 45 and 55 tokens of adverb placement and passives, respectively.

\section{Treatment}

The treatment involved participants listening to an audiobook that was selected together with the teacher on the course. The book (called 'Peaks and Valleys' written by Spencer Johnson) is a relatively easy text about self-development, or 'life skills'. As such it was deemed to be relevant for freshmen students. The audiobook is commercially available and is recorded by a professional reader. The Flesch-Kincaid Grade Level readability, which indicates an expected average grade level that can understand the text, was between 7 and 8 (with Flesch reading scores between 67 and 77). As such it was considered of an appropriate level for the intermediate participants in the study.

The book was digitally enhanced using a standard personal computer and audio-video editing software, Adobe Premier CS2. First, all instances of the adverbs placed between subject and verb, and passive structures were identified. Next, the volume of each target item was raised by about 20 to 30 percent. This was thought to be sufficient to make the items stand out but not so much that it would interrupt the listening experience. The audiobook was then converted to an $\mathrm{mp} 3$ file, and subsequently distributed to participants using the University's course management system, where participants downloaded the files and transferred them to their mobile phones.

Participants were told by their teacher to enjoy listening to the story and not to memorize vocabulary or grammar items. They were told that the book would be talked about in class 
Journal of Second Language Teaching and Research Volume One Issue One

and that they would be asked about the content of the book on their final exam. They were asked to listen to the book only once. They were not given any further instructions, nor were they told about the target structures or that they were going to be tested on them. The target features were not covered during classroom hours.

\section{Tests}

A timed GJT was administered as a pretest and as a posttest. This test consisted of 60 sentences, 30 of which contained the target structures, 15 adverb placement (e.g., The minister angrily asked the reporter to leave) and 15 passives (e.g., I lost in the middle of the crowd. See Appendix 2 for the complete list of test items). Of the sentences containing adverb placement, seven were grammatical and eight ungrammatical sentences, and of those containing passives, eight were grammatical and seven ungrammatical. The other 30 items consisted of sentences with distractor items (e.g., He completed his studies successful). At both test administrations the order of the items was changed. In the test, sentences were shown on the computer screen and participants had to press the 'enter' key if they thought the sentence on the screen was correct, and the left-hand 'shift' key if they thought it was not. The keys were labelled with stickers indicating 'correct' and 'incorrect'. There were eight practice sentences during which the researcher was present to give clarification where needed. The learners were told that they might not be able to respond to all the items in time but that they should try to answer as many as they could. Although GJTs are not without their drawbacks (see Birdsong, 1989), the timed GJT seemed appropriate as it has been used as a measure of implicit knowledge (cf. Han and R. Ellis, 1998), which seemed the most likely outcome of exposure to enriched input as in this study.

To measure internal consistency of the items on the GJT we calculated Kuder-Richardson 20 (KR-20) scores ${ }^{1}$. The results are as follows (Table 1):

\section{Table 1: Reliability figures of GJT}

\begin{tabular}{|l|l|l|}
\hline & Pretest & Posttest \\
\hline Adverb placement & 0.850 & 0.619 \\
\hline Passive & 0.715 & 0.878 \\
\hline
\end{tabular}

\footnotetext{
${ }^{1}$ We chose KR20 as it can be applied to both dichotomous and continuous data.
} 
Journal of Second Language Teaching and Research Volume One Issue One

As the table shows, in general the scores are acceptably high, with the exception of the adverb placement posttest, which is somewhat lower.

\section{Control}

The 67 participants (randomly) assigned to the control group completed the same tests and treatments as participants in the aural input enhancement group, but listened to the audiobook in its original format, i.e. without any alteration.

\section{Analysis}

To measure performance on the pre and posttests on the GJT, participants were given one point for each correct item and zero points for each incorrect or missing item.

\section{Results}

1. What are the effects of aural input enhancement in extensive mobile listening practice on the acquisition of English 1) adverb placement and 2) passives?

The descriptive results for acquisition are presented as percentages (Table 1) and gain scores (Table 2) for both target structures.

Table 2: Descriptive Statistics for Pretest and Posttest Scores

\begin{tabular}{|l|l|l|l|l|l|}
\hline \multicolumn{2}{|c|}{} & \multicolumn{2}{|l|}{ Pretest } & \multicolumn{2}{l|}{ Posttest } \\
\cline { 3 - 6 } \multicolumn{2}{|c|}{} & Mean & $S D$ & Mean & $S D$ \\
\hline \multirow{2}{*}{$\begin{array}{l}\text { Group 1 (aural } \\
\text { enhancement) } \\
N=7\end{array}$} & $\begin{array}{l}\text { adverb } \\
\text { placement }\end{array}$ & 57.14 & 17.15 & 59.04 & 19.41 \\
\cline { 2 - 6 } & passives & 74.29 & 12.43 & 71.43 & 26.31 \\
\cline { 2 - 6 } & distractors & 74.76 & 12.56 & 79.52 & 17.58 \\
\hline $\begin{array}{l}\text { Group 2 } \\
\text { (control) } \\
N=9\end{array}$ & $\begin{array}{l}\text { adverb } \\
\text { placement }\end{array}$ & 66.67 & 14.53 & 66.67 & 14.53 \\
\cline { 2 - 6 } & passives & 68.89 & 20.55 & 71.11 & 15.98 \\
\cline { 2 - 6 } & distractors & 74.07 & 14.98 & 80.37 & 15.13 \\
\hline
\end{tabular}

As table 2 shows, mean scores on the pretest for adverb placement were $57.14(S D=17.15)$ and for passives 74.29 ( $S D=12.43)$, so participants had greater prior knowledge of passives than adverb placement. The scores for the control group were $66.67(S D=14.53)$ and 68.89 
Journal of Second Language Teaching and Research Volume One Issue One

( $S D=20.55$ ), and showed no significant difference with the treatment group (t-test scores for adverb placement, passives and distractors were $p=.09 ; p=.12 ; p=.86$, respectively).

In order to examine whether there was any effect for input enhancement, the gain scores (of each individual) of both groups from pretest to posttest were compared using a MANNWHITNEY U-test. This type of statistical analysis was deemed appropriate considering the small sample size and considering the fact that the data was not normally distributed (Table 3).

Table 3: Mann-Whitney U-Test for Group Differences of the Gain Scores in Each Target Item

\begin{tabular}{|l|l|l|l|l|l|}
\hline Gain & Group & $N$ & Mean rank & $\begin{array}{l}\text { Sum of } \\
\text { Ranks }\end{array}$ & Sig. \\
\hline \multirow{2}{*}{$\begin{array}{l}\text { Adverb } \\
\text { placement }\end{array}$} & $\begin{array}{l}\text { Volume } \\
\text { (experimental) }\end{array}$ & 7 & 7.57 & 53.00 & .536 \\
\cline { 2 - 5 } & Control & 9 & 9.22 & 83.00 & \\
\hline Passives & Volume & 7 & 8.07 & 56.50 & .758 \\
\cline { 2 - 5 } & Control & 9 & 8.83 & 79.50 & \\
\hline Distractors & Volume & 7 & 8.36 & 58.50 & .918 \\
\cline { 2 - 5 } & Control & 9 & 8.61 & 77.50 & \\
\hline
\end{tabular}

The results suggest that there was no difference between the input enhancement and the control group and this was found to be statistically significant $(Z=-.695$; -.321 ; and -.107 , for adverb placement, passives, and distractor items respectively $(p=<.05)$. In other words, there were no significant group differences between the experimental and the control groups; there was no effect for aural input enhancement on either adverb placement or passives.

\section{How can mobile devices be used for 1) encouraging and 2) investigating extensive listening practice?}

Most learners used their MP3 players to listen to the audiobook and a smaller number used their cellphones. This was somewhat surprising as we had expected participants to be using their cellphones, but clearly they favoured MP3 players, perhaps for their greater functionality. Most learners $(N=37)$ listened to the audiobook on the subway or the bus 
while commuting, reflecting the importance of portability in encouraging extensive listening. The remaining students listened at home, but usually just before going to bed, implying that extensive listening is considered an informal activity, best conducted in a relaxed context. This is different from the way listening is practised in most language classrooms, where the emphasis is on formal instruction and feedback.

Although generally participants said they liked using their mobile devices to listen to the book, as researchers we faced a number of issues. Firstly, a number of participants $(N=51)$ said they had not completed listening to the audiobook and we had to eliminate them from the dataset. Clearly, this is a limitation of investigating out-of-class learning. However, we were keen to allow learners to access the materials in their own time and in their preferred place, in order to maximise the potential benefit of using the mobile devices. By linking the classroom with students' personal lives, the aim is to encourage students to see language learning - which of course involves the acquisition of a skill, rather than discrete knowledge - as an ongoing activity, rather than one that can be isolated in an educational setting. Language is, by definition, contextualised and only outside the classroom can the connection with learners' lives be made and can language be practised in an authentic and contextually rich environment. For this reason the use of mobile devices was an important aspect of this study.

Finally, the use of mobile devices allowed us to investigate a novel type of input enhancement, using aural rather than textual enhancement.

\section{Discussion}

This study investigated whether aural input enhancement helps $L 2$ learners acquire formal aspects of English. Data analysis revealed no meaningful enhancement effect on either adverb placement or passive structures. Although the results are tentative due to the small sample size, we would like to offer some possible explanations.

First, the ineffectiveness of aural input enhancement may be partly due to the nature of the mode of input rather than to the nature of the input enhancement, especially compared with the reported effectiveness of written (textual) input enhancement (e.g., Doughty, 1991; Jourdenais et al., 1995; Lee, 2007). Some researchers (e.g., Sharwood Smith, 1991) have pointed out that learners' intake of manipulated input could be largely dependent on individual differences such as working memory, strategies used, and also cognitive load. Similarly, Leow's studies $(1993,1995)$ suggested that learners' intake of externally 
Journal of Second Language Teaching and Research Volume One Issue One

manipulated input may, to some extent, depend on cognitive constraints and the cognitive strategies used by the students. In particular the time aspects involved in listening presents learners with a greater cognitive constraint than reading. Therefore, it is possible that learners' cognitive processing was mainly dedicated to understanding meaning rather than to the enhanced forms (especially considering the fact that no grammar-related instruction was given).

Another possible explanation could be that learners' fail to process a form that they may have noticed. Williams' studies $(1999,2005)$ showed that, especially in meaning-oriented tasks, further processing of noticed input is necessary for the underlying rules to be formulated:

\begin{abstract}
"if learning distributional rules is critically dependent upon the subjects initially paying attention to relations between elements in the input, then it follows that even the simplest rules might not be learned if the subjects for some reason fail to attend to those relationships" (1999 p. 32).
\end{abstract}

What this suggests for the current study is that learners may have failed to allocate attention to the relationships between different grammar elements (e.g., to know where to place an adverb in a sentence, a learner needs to know what an adverb is as well as other word classes, and the relationship of these to each other) or at least did not make the formmeaning connections necessary to establish their underlying rules (cf. Baddeley, 1991). In addition, the lack of explicit instruction and the fact that learners were not explicitly asked to focus on the target form may have prevented them from allocating attention to the target grammar (Murphy \& Shapiro, 1994). Also, the lack of feedback may have prevented them from noticing the target forms or generating their underlying rules (Baddeley et al. 1998; Williams, 1999).

Finally, it is important to remind the reader that the amount of exposure that learners received was small; they listened to only one, fairly short audiobook, and were exposed to only 55 and 65 exemplars of the two target structures. It is also possible that they would need, if not more, than at least more repeated exposure to the target structure, for example by listening to several books over an extended period (weeks, months) of time.

Above we have highlighted some methodological challenges in using mobile technologies, and in particular investigating out-of-class learning. Two considerable challenges are 
controlling 1) exposure to the target input, and 2) the effect of extraneous variables. Mobile devices, by their very nature, make it possible for learners to access learning materials at any time and in any place. This makes them useful, but makes the context in which they are accessed part of the learning experience. As this cannot be controlled for, it becomes difficult to make definitive statements about the benefits or otherwise of, for example, extensive listening; one participant may have listened to the materials in dead silence in the library, paying full attention, while another might have played it in a noisy car while simultaneously paying attention to the road.

In addition to the effects of the surrounding and differences therein, we found that participants had not all listened to the materials once only. Some had listened more than once, others had skipped parts. Clearly, from a methodological point of view, the control afforded by a laboratory, or even a classroom environment, is absent. This increases the ecological validity of the study (cf. Van Lier, 1996), but decreases its reliability. A major challenge in investigating out-of-class learning, and the use of mobile technologies which, if their potential benefit is to be researched, necessarily are going to be used outside of formal educational contexts, is in balancing validity and reliability and in finding ways to mitigate the potential negative impact, while preserving their benefits.

\section{Conclusions}

This study attempted to investigate whether aural input enhancement through volume increase can benefit acquisition of grammatical forms. Our study revealed no significant effects of increased volume on acquiring target features: adverb placement and passives. We would like to be tentative in making this claim due to some limitations to this study. The number of participants in the study is obviously small. The reason for this is that we found that some participants had not completed listening to the story by the end of the week and we had to eliminate them from the dataset. This is one of the challenges of investigating language acquisition outside the classroom; it is clearly more difficult to control for such variables. This meant that the data was not normally distributed and that, even if using statistical methods appropriate for small sample sizes, we have to be careful to be tentative in our conclusions.

Nonetheless, despite the small number of participants, we do feel that the findings are relevant. By investigating extensive listening in its most natural environment, and by using tools that the teenage learners in this study are most comfortable with, we feel that the study benefits from greater ecological validity (Van Lier, 1996). Laboratory conditions, although 
Journal of Second Language Teaching and Research Volume One Issue One

affording greater control in terms of data collection, may not be suitable if the results are to be a true indication of the potential effect of extensive listening activities.

A final limitation is that we were unable to control completely the number of times participants listened to the story. Although the teacher asked participants to listen to the story only once and the questionnaire asked them how often they had heard the story, it is still possible, although unlikely, that participants listened to the story more than once without saying so.

Despite these limitations we feel it is important to investigate language learning in its natural environment. We need to investigate and learn from our learners' preferences for engaging with pedagogic materials and, where appropriate, match the delivery with these preferences, rather than forcing access to resources through existing channels. Even when studies such as this one find no learning gains, the challenge is not to dismiss the methods, but is to find ways to deliver instruction or materials in new ways that better match the delivery medium and maximise their potential.

\section{References}

Adams, M. J. (1998). The three-cueing system' in F. Lehr and J. Osborn (eds.). Literacy for all: Issues in teaching and learning. New York: Guilford Press.

Baddeley, A. (1991). Human memory: Theory and practice. Hove: Lawrence Erlbaum.

Baddeley, A., Gathercole, S., \& Papagno, C. (1998). The phonological loop as a language learning device. Psychological Review, 105, 158-173.

Birdsong, D. (1989). Metalinguistic performance and interlinguistic competence. New York: S pringer.

Chen, N., Hsieh, S., \& Kinshuk. (2008). Effects of short-term memory and content representation type on mobile language learning. Language learning \& technology, 12(3), 93-113.

Chinnery, G. (2006). Going to the MALL: Mobile assisted language learning. Language learning \& technology, 10(1), 9-16.

Cross, J. (2007). Informal learning: Rediscovering the paths that inspire innovation and pe rformance. San Francisco: Pfeiffer.

Day, R., \& Bamford, J. (1998). Extensive reading in the second language classroom.

Cambridge: Cambridge University Press.

Dias, J. (2002a). Cell phones in the classroom: Boon or bane? C@lling Japan, 10(2), 16-21. 
Journal of Second Language Teaching and Research Volume One Issue One

Dias, J. (2002b). Cell phones in the classroom: Boon or bane? Part 2. C@lling Japan, 10(3), 8-13.

Doughty, C. (1991). Second language instruction does make a difference: Evidence from an empirical study of SL relativization. Studies in Second Language Acquisition, 13, 4 31-469.

Ellis, N. (2002). Frequency effects in language acquisition: A review with implications for theories of implicit and explicit language acquisition. Studies in Second Language Acquisition, 24, 143-188.

Ellis, R. (2008). The Study of Second Language Acquisition. Oxford University Press, USA. Fotos, S. (1994). Integrating grammar instruction and communicative language use through grammar consciousness-raising tasks. TESOL Quarterly, 28, 323-351.

Gascoigne, G. (2006) Toward an understanding of incidental input enhancement in computerized L2 Environments, CALICO Journal, 24(1), 147-162.

Jourdenais, R., Ota, M., Stauffer, S., Boyson, B., \& Doughty, C. (1995). Does textual enhancement promote noticing? A think-aloud protocol analysis. In R. Schmidt (Ed.), Attention and awareness in foreign language learning (pp. 183-216). Honolulu: University of Hawai'i, Second Language Teaching \& Curriculum Center.

Kaplan, R., \& Baldauf, R., (1997). Language planning from practice to theory. Clevedon: Mul tilingual Matters.

Kukulska-Hulme, A., \& Traxler, J. (2007) Design for mobile and wireless technologies. In H. Beetham \& R. Sharpe (eds). Rethinking pedagogy for the digital age. London: Rout ledge.

Lave, J., \& Wenger, E. (1991). Situated learning: Legitimate peripheral participation. Cambridge: Cambridge University Press.

Lee, S. (2007). Effects of textual enhancement and topic familiarity on Korean EFL students' reading comprehension and learning of passive form. Language Learning, 57, 87118.

Lee, S., \& Huang, H. (2008). Visual input enhancement and grammar learning: A metaa nalytic review. Studies in Second Language Acquisition, 30, 307-331.

Leow, R. (1993). To simplify or not to simplify: A look at intake. Studies in Second Language Acquisition, 15, 333-355.

Leow, R. (1995). Modality and intake in SLA. Studies in Second Language Acquisition, 17, 7 9-89.

Levy, M., \& Kennedy, C. (2005). Learning Italian via mobile SMS. In A. Kukulska-Hulme \& J. Traxler (Eds.) 76-83. Mobile Learning: A Handbook for Educators and Trainers. London: Taylor and Francis 
Motiwalla, L. F. (2007) Mobile learning: A framework and evaluation, Computers \& Education 49 (3), pp. 581-596.

Murphy, G., \& Shapiro, A. (1994). Forgetting verbatim information in discourse. Memory and Cognition, 22, 85-94.

McCarty, S. (2005). Spoken internet to go: Popularization through podcasting. JALT-CALL Journal, 1(2), 67-74.

Norbrook, H., \& Scott, P. (2003). Motivation in mobile modern foreign language learning. In J. Attewell, G. Da Bormida, M. Sharples, \& C. Savill-Smith (Eds.), MLEARN 2003: Learning with mobile devices (pp.50-51). London: Learning and Skills Development Agency.

Ogata, H. \& Yano, Y. (2003). How ubiquitous computing can support language learning. Retrieved from: http://www-yano.is.tokushimau.ac.jp/ogata/clue/ogata-kest2003.pdf

Patten, B., Sanchez, I., \& Tangney, B. (2006). Designing collaborative, constructionist and C ontextual applications for handheld devices. Computers \& Education, 46(3), 294-30 8.

Reber, A. (1993). Implicit learning and tacit knowledge: An essay on the cognitive unconscious. New York: Oxford University Press.

Reinders, H., \& Lewis, M. (2009). Podquests: Language games on the go. In Andreade, M. ( Ed.), Language Games. Alexandria: TESOL.

Renandya, W., \& Farrell, T. Teacher, the tape is too fast! Extensive listening in ELT. ELT Journal, Oxford University Press.

doi: 10.1093/elt/ccq015

Renandya, W., \& Fang, Z. (2003). Where is the listening? Guidelines, 25(1), 12- 16.

Sharwood Smith, M. (1991) Speaking to many minds: On the relevance of different types of language information for the L2 learner, Second Language Research, 7, 118-132.

Sharwood Smith, M. (1993). Input enhancement in instructed SLA: Theoretical bases, Studies in Second Language Acquisition, 15, 165-179.

Spada, N., \& Lightbown, P. (1993). Instruction and the development of questions in the L2 classroom. Studies in Second Language Acquisition, 15, 205-221.

Stockwell, G. (2007). Vocabulary on the move: Investigating an intelligent mobile phone-bas ed vocabulary tutor. Computer Assisted Language Learning, 20(4), 365-383.

Thornton P., \& Houser C. (2003). Using mobile web and video phones in English language $t$ eaching: Projects with Japanese college students. In B. Morrison, C. Green \& G. M otteram (Eds.), Directions in CALL: Experience, experiments and evaluation (207224). Honk Kong: English Language Centre, Hong Kong Polytechnic University.

Thornton, P., \& Houser, C. (2005). Using mobile phones in English Education in Japan. Jour 
nal of Computer Assisted Learning, 21, 217-228.

Trifanova, A., Knapp, J., Ronchetti, M., \& Gamper, J. (2004). Mobile ELDIT: Challenges in the transitions from an e-learning to an m-learning system. Trento, Italy: University of Trento. Retrieved from:

http://eprints.biblio.unitn.it/archive/00000532/01/paper4911.pdf

Van Lier, L. (1996). Interaction in the language curriculum: Awareness, autonomy and authenticity. London: Longman.

VanPatten, B. (1996). Input processing and grammar instruction: Theory and research. Nordwood. NJ: Ablex.

Warschauer, M., \& Healey, D. (1998). Computers and language learning: An overview. Language Teaching, 31, 57-71.

White, J. (1998). Getting the learners' attention: A typographical input enhancement study. In C. Doughty \& j. Williams (Eds.), Focus on form in classroom second language acquisition (85-113). Cambridge: Cambridge University Press.

White, C. (2006). Distance learning of foreign languages. Language Teaching, 39(4), 247-26 7.

Williams, J. (1999). Memory, attention, and inductive learning. Studies in Second Language Acquisition, 21, 1-48.

Zhang, W. 2005. An investigation of the effects of listening programmes on lower secondary students' listening comprehension in P R C. [Unpublished MA dissertation], SEAMEO Regional Language Centre, Singapore. 


\section{Biodata}

Dr. Hayo Reinders (www.innovationinteaching.org) is Head of Learner Development at Middlesex University in London. He is also Editor of Innovation in Language Learning and Teaching, and Convenor of the AILA Research Network for CALL and the Learner. Hayo's interests are in CALL, autonomy, and out-of-class learning. He is a speaker for the Royal Society of New Zealand. His most recent books are on teacher autonomy, teaching methodologies, and second language acquisition and he edits a book series on 'New Language Learning and Teaching Environments' for Palgrave Macmillan.

Min Young Cho (mycho@hawaii.edu) is a Ph.D student at the University of Hawaii at Manoa. Her research interests centers on implicit/explicit grammar instruction with a special focus on input enhancement. She is also interested in L2 motivation and is currently conducting motivation study of Korean English learners. 


\section{Appendix 1: Survey after posttest}

What was your English score on the university entrance exam (or if you do not have this score, what was your most recent TOEFL or TOEIC score)?

Where did you listen to the audio book most? (e.g., on the bus, or on the subway, or at home).

What device did you use to listen to the book? (e.g. Mobile phone, MP3 player, computer)

How many times did you listen to the audio book?

(Choice: once, twice, more than twice)

Have you read or listened to this book before? (Either in English or in Korean)

:Yes/ No

When did you finish listening to the book?

(Choice: Today, Yesterday, Saturday, Friday, Thursday, Wednesday, Tuesday, Last Monday)

\section{Appendix 2: Complete list of test items}

\section{Grammaticality Judgment Test Items (*: ungrammatical items)}


Journal of Second Language Teaching and Research Volume One Issue One

\section{Adverb placement}

Thousands of people were eagerly awaiting him.

*He threw quickly her letter into a rubbish bin.

${ }^{*}$ The teacher answered patiently all her questions.

${ }^{*}$ It is very important to see positively things.

*Last week, I won unexpectedly the first prize at soccer.

My father sincerely loves my mother.

*Pusan needs ungently a second airport.

He asked quietly her to leave the church.

*You need to see regularly a dentist.

${ }^{*}$ The patient needs to see regularly a doctor.

The manager angrily asked the guest to leave the hotel.

When she got money, she immediately bought new clothes.

When he got the news, he immediately phoned her.

The government will definitely raise taxes next year.

The policeman urgently asked the reporter to leave.

\section{Passive structure}

*He injured when he fell off his bike.

During the war, many people were killed.

*Two thousand people will hire to organize the Olympic game.

Access to the data is limited to university staff.

The speed limit is not obeyed by most drivers.

*I lost in the middle of the crowd.

Our essays were collected after the exam. 
Journal of Second Language Teaching and Research Volume One Issue One

*Many books have translated from English to Korean.

The entire valley can be seen from the mountain.

*Before she graduated, she already offered a job with a law firm.

*He fired because he did not do his job.

The broken computer was fixed today.

The pilot was trained in the United States.

Nobody was hurt in the accident.

*I confused because everyone gave me different opinions.

Distractors

${ }^{*}$ People look negative at politicians.

*We need urgent to find our solution to our money problems.

He has learned English for three years, but still speaks poorly.

${ }^{*}$ The student followed the teacher unwilling.

${ }^{*}$ The car drove too slow.

*All students should study hardly.

${ }^{*} \mathrm{He}$ always works very efficient.

I visit my family in Europe frequently.

${ }^{*}$ The waiter asked us polite to move to another table.

*We cautious entered the empty house.

She always works efficiently.

${ }^{*} \mathrm{He}$ is famous because he sings beautiful.

*My mother occasional brings home some bananas.

${ }^{*}$ My brother and I often see things different.

*It was cold and it snowed heavy. 
Journal of Second Language Teaching and Research Volume One Issue One

*He completed his study successful.

*He will not get promoted because he does not work accurate.

He finished his meal very quickly.

He spoke so quickly that nobody understood him.

When we came out of the restaurant, a man suddenly came up to us.

Every player in this team has to practice tonight.

In the mountains, you have to walk very carefully.

I am curious about his ideas.

He spends his money easily.

We drove very slowly to enjoy the views.

The child disappeared suddenly.

Many people think Einstein is a genius.

He always pronounces every word clearly.

After the war, people returned to their homes immediately.

He ran so quickly that he arrived home before us.

Grammaticality Judgment Test Items (in the order of presentation in the pretest)

Thousands of people were eagerly awaiting him.

*People look negative at politicians.

*He threw quickly her letter into a rubbish bin.

*The teacher answered patiently all her questions.

${ }^{*} \mathrm{He}$ injured when he fell off his bike.

During the war, many people were killed.

*We need urgent to find our solution to our money problems.

*Two thousand people will hire to organize the Olympic game. 
Journal of Second Language Teaching and Research Volume One Issue One

The manager angrily asked the guest to leave the hotel.

He has learned English for three years, but still speaks poorly.

*The student followed the teacher unwilling.

Access to the data is limited to university staff.

*It is very important to see positively things.

${ }^{\star}$ The car drove too slow.

*Last week, I won unexpectedly the first prize at soccer.

The speed limit is not obeyed by most drivers.

My father sincerely loves my mother.

* l lost in the middle of the crowd.

*All students should study hardly.

He finished his meal very quickly.

He spoke so quickly that nobody understood him.

When we came out of the restaurant, a man suddenly came up to us.

${ }^{*}$ Pusan needs ungently a second airport.

Every player in this team has to practice tonight.

Our essays were collected after the exam.

*Many books have translated from English to Korean.

I visit my family in Europe frequently.

The entire valley can be seen from the mountain.

*He always works very efficient.

*The waiter asked us polite to move to another table.

*Before she graduated, she already offered a job with a law firm.

${ }^{*} \mathrm{He}$ asked quietly her to leave the church. 
Journal of Second Language Teaching and Research Volume One Issue One

${ }^{*} \mathrm{He}$ fired because he did not do his job.

In the mountains, you have to walk very carefully.

When she got money, she immediately bought new clothes.

The broken computer was fixed today.

I am curious about his ideas.

${ }^{*} \mathrm{He}$ is famous because he sings beautiful.

He spends his money easily.

The pilot was trained in the United States.

*We cautious entered the empty house.

She always works efficiently.

When he got the news, he immediately phoned her.

${ }^{*}$ He completed his study successful.

*You need to see regularly a dentist.

${ }^{*} \mathrm{He}$ will not get promoted because he does not work accurate.

The government will definitely raise taxes next year.

We drove very slowly to enjoy the views.

The child disappeared suddenly.

Many people think Einstein is a genius.

The policeman urgently asked the reporter to leave.

He always pronounces every word clearly.

*My mother occasional brings home some bananas.

After the war, people returned to their homes immediately.

${ }^{*}$ My brother and I often see things different.

*I confused because everyone gave me different opinions. 
*The patient needs to see regularly a doctor.

*It was cold and it snowed heavy.

Nobody was hurt in the accident.

He ran so quickly that he arrived home before us.

\section{Appendix 3 : Sample Enhanced items from text}

Adverb placement

1. Once, he thought he had finally found what he wanted.

2. Soon, he proudly told some of his friends about what he'd learned on the peak.

Passive

1. But when he viewed the valley from above, he saw the pale brown stagnant air that was trapped there.

2. Both kinds of highs and lows are scattered about and connected in similar ways.

\section{Sample grammaticality judgment test (GJT) items}

Adverb placement:

1. *Auckland needs urgently a second motorway.

2. *You need to see regularly a dentist.

3. The minister angrily asked the reporter to leave.

4. The government will definitely raise taxes next year.

Passive:

1. *Before she graduated, she offered a position with a law firm.

2. * When he fell, he injured very badly.

3. Usually, the speed limit is not obeyed by most drivers.

4. Our papers are going to be collected immediately.

\section{Sample survey questions}

\section{A. Comprehension}


1. What was the name of the main character? (The person who are listening to the "peaks and valleys" story)
a. Danial
b. Michael
c. Chris
d. Nathanial

2. What happened when young man's suggested that the company invest in growing new markets they'd never gone into before?
a. The boss respected his ideas and agreed to invest to the markets.
b. The boss was reluctant, but the young man persuaded him.
c. The boss was pleased with what they are now, so he refused to invest in new markets.

\section{B. Informal language learning}

1. Where did you listen to the audio book most?
a. the bus
b. on the subway
c. at home
d. Not listed (specify).

2. What device did you use to listen to the book?
a. Mobile phone
b. MP3 player c. computer
d. Not listed (specify)

3. How many times did you listen to the audio book?
a. once
b. twice
c. more than twice 